\title{
COVID-19 Associated With Concomitant Varicella Zoster Viral Encephalitis
}

\author{
Pavan Patel, DO, Anishee Undavia, MD, Rabia Choudry, MD, Yan Zhang, MD, and \\ Aparna M. Prabhu, MD, MRCP
}

Neurology: Clinical Practice April 2021 vol. 11 no. 2 e219-e221 doi:10.1212/CPJ.0000000000000902

\author{
Correspondence \\ Dr. Patel \\ Patelpav@einstein.edu
}

Coronavirus disease 2019 (COVID-19) is a novel infectious disease caused by severe acute respiratory syndrome coronavirus-2 (SARS-CoV-2). Patients can be asymptomatic or symptomatic with severity determined by age and comorbid conditions. Common early symptoms are fever, cough, dyspnea, myalgia, headache, and diarrhea. In addition to respiratory complications, other systems involved include genitourinary, gastrointestinal, and cardiac. ${ }^{1}$

Neurologic complications such as encephalopathy were initially presumed to be because of multisystem involvement. Retrospective studies of patients with COVID-19 demonstrated multiple neurologic complications affecting central and peripheral nervous systems including dizziness, headache, hypogeusia, hyposmia, ischemic/hemorrhage stroke, and Guillain-Barre syndrome. ${ }^{2}$ There was a single case report of hemorrhagic necrotizing encephalopathy reported in COVID-19, with imaging features of enhancement of bilateral thalami and medial temporal lobes. ${ }^{3}$ To our knowledge, there have been no cases reported of coinfection with another virus during active COVID-19 infection resulting in neurologic manifestations.

Here, we discuss one of the first known cases of COVID-19 infection and concomitant Varicella zoster virus (VZV) encephalomyelitis. It is unclear if the VZV infection is provoked by underlying COVID-19 or if VZV is simply a coinfection. Identifying this is important not only because imaging characteristics are similar to those in COVID-19-related necrotizing encephalopathy but also because VZV has definitive treatment that can be offered.

\section{Case}

An 83-year-old White man with hypertension, hyperlipidemia, and chronic kidney disease presented with altered mental status and agitation. He had been discharged from an outside hospital 1 week earlier, diagnosed with COVID-19 by PCR.

He came in unresponsive with left-gaze deviation. He was stuporous, arousable to noxious stimuli, and nonverbal. Brainstem reflexes were present albeit asymmetric. He had minimal motor withdrawal in all 4 extremities and was suspected to have had a seizure but did not respond to antiepileptic agents.

MRI of the brain with contrast demonstrated restricted diffusion and T2-FLAIR hyperintensity in the left insula, medial temporal lobe, and hippocampus. This was believed to correlate with his suspected seizure (figure, A, B). Susceptibility in the left medial temporal lobe (figure, C) was concerning for herpes simplex virus (HSV) encephalitis.

Therefore, IV acyclovir was initiated empirically. CSF showed $193 \mathrm{c} / \mathrm{cmm}$ white blood cells (86\% lymphocytes), $19,000 \mathrm{c} / \mathrm{cmm}$ red blood cells, glucose of $114 \mathrm{mg} / \mathrm{dL}$, and an elevated

\section{MORE ONLINE}

COVID-19 Resources

For the latest articles, invited commentaries, and blogs from physicians around the world NPub.org/COVID19 


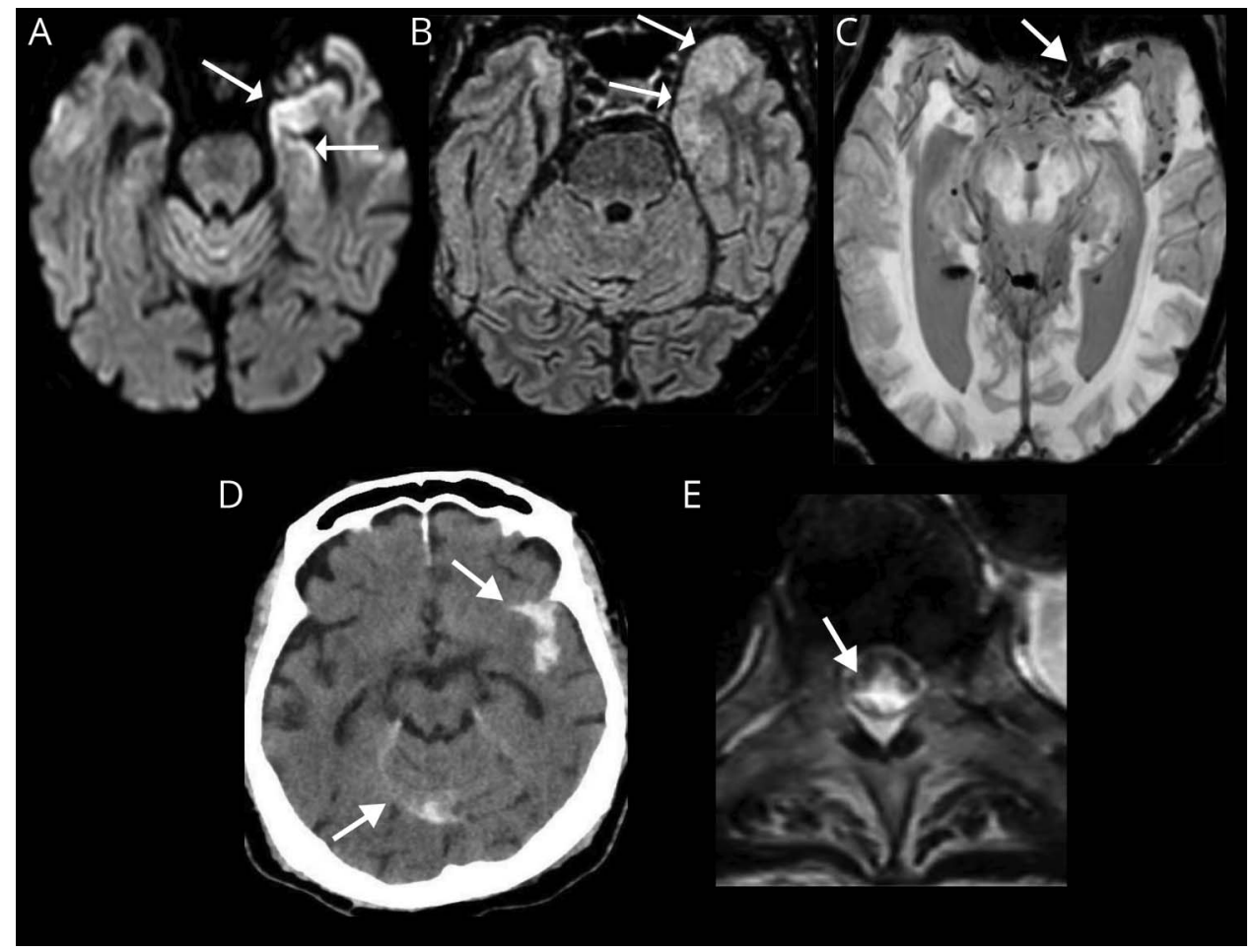

(A) Initial MRI with axial diffusionweighted imaging demonstrating restricted diffusion in the left temporal lobe (day 4 of admission). (B) Initial MRI with axial FLAIR demonstrated hyperintensity in the left medial and anterior temporal lobe (day 4 of admission). (C) Initial MRI with axial susceptibility weighted imaging demonstrating susceptibility in the left temporal lobe (day 4 of admission). (D) Repeat noncontrast CT of the head showing acute subarachnoid hemorrhage with IV extension (day 8 of admission). (E) Axial T2-weighted thoracic spine MRI showing segmental hyperintensity in the dorsal columns from T5-T6 (day 8 of admission). VZV = Varicella zoster virus.

protein of $427.4 \mathrm{mg} / \mathrm{dL}$. CSF was analyzed using a BioFire panel which detects several common bacterial/viral causes of meningitis/encephalitis by PCR. The results were positive for VZV and negative for the remaining pathogens on the panel, including HSV-1.

On day 8 of admission, our patient underwent emergent CT head after he was noted to have decreased responsiveness and diminished movement in his legs. CT of the head showed subarachnoid hemorrhage in the bilateral middle cerebral artery territories (figure, D). CT angiogram confirmed the presence of a saccular aneurysm of the left ICA. MRI of the spine showed restricted diffusion and T2-hyperintensity at thoracic T5-T6 (figure, E) suspicious for a spinal cord infarct.

He was maintained on acyclovir, albeit without response and was eventually placed in hospice. He was never treated with corticosteroids or IL-6-receptor blockers.

\section{Discussion}

We report a case of VZV encephalomyelitis and vasculitis in a patient infected with COVID-19. VZV reactivation is a wellknown phenomenon typically in immunocompromised individuals and can cause neurologic complications such as ischemic/hemorrhagic stroke, vasculitis, myelitis, or neuropathy. ${ }^{4} \mathrm{VZV}$ is known to cause vasculopathy and resultant aneurysms with or without hemorrhage. Detection of concomitant VZV encephalitis is important because it is potentially treatable (with acyclovir).

To our knowledge, this is the first reported case of COVID-19 infection potentially resulting in VZV reactivation with such devastating results. It is possible that COVID-19 produced an immunosuppressed state that allowed VZV to reactivate. There have been reports of $\mathrm{T}$-cell exhaustion in patients with severe COVID-19, but given its novelty, mechanisms still need to be determined. Other putative mechanisms causing immunosuppression include the use of corticosteroids/IL-6-receptor blocker (e.g., Sarilumab) in patients with COVID-19.

In addition, this patient showed evidence of spinal cord infarcts (supported by restricted diffusion). VZV has been reported to cause cord infarcts likely because it can produce a hypercoagulable state. ${ }^{5,6}$ COVID-19 is known to cause a hypercoagulable state with patients tending to have high $\mathrm{D}$-dimers, fibrinogen, and fibrin degradation products. ${ }^{7}$ However, it is difficult to elucidate if a single virus or interactions of both viruses contributed to the hypercoagulable state in this patient.

\section{Conclusion}

COVID-19 is a devastating virus that can cause a multitude of complications across almost all the systems in the human body. This case is an important first report showing VZV infection and its resultant complications, seen in association with SARS-CoV-2. 


\section{Study Funding}

No targeted funding reported.

\section{Disclosure}

P. Patel, A. Undavia, R. Choudry, Y. Zhang, and A.M. Prabhu report no disclosures relevant to the manuscript. Full disclosure form information provided by the authors is available with the full text of this article at Neurology.org/cp.

\section{Publication History}

Received by Neurology: Clinical Practice May 5, 2020. Accepted in final form June 23, 2020.

\section{Appendix Authors}

\begin{tabular}{lll}
\hline Name & Location & Contribution \\
\hline $\begin{array}{l}\text { Pavan Patel, } \\
\text { DO }\end{array}$ & $\begin{array}{l}\text { Einstein Medical } \\
\text { Center, } \\
\text { Philadelphia, PA }\end{array}$ & $\begin{array}{l}\text { Designed and conceptualized } \\
\text { study; acquisition of data, } \\
\text { analysis and interpretation. } \\
\text { Bibliographic review and drafted } \\
\text { manuscript. }\end{array}$ \\
\hline $\begin{array}{l}\text { Anishee } \\
\text { Undavia, MD }\end{array}$ & $\begin{array}{ll}\text { Einstein Medical } \\
\text { Center, } \\
\text { Philadelphia, PA }\end{array}$ & $\begin{array}{l}\text { Study concept and design. } \\
\text { Supervision and revision of } \\
\text { manuscript. }\end{array}$ \\
\hline
\end{tabular}

Appendix (continued)

\begin{tabular}{lll}
\hline Name & Location & Contribution \\
\hline $\begin{array}{l}\text { Rabia } \\
\text { Choudry, MD }\end{array}$ & $\begin{array}{l}\text { Einstein Medical } \\
\text { Center, } \\
\text { Philadelphia, PA }\end{array}$ & $\begin{array}{l}\text { Supervision and revision of } \\
\text { manuscript. }\end{array}$ \\
\hline $\begin{array}{l}\text { Yan Zhang, } \\
\text { MD }\end{array}$ & $\begin{array}{l}\text { Einstein Medical } \\
\text { Center, } \\
\text { Philadelphia, PA }\end{array}$ & $\begin{array}{l}\text { Supervision and revision of } \\
\text { manuscript. }\end{array}$ \\
\hline $\begin{array}{l}\text { Aparna M. } \\
\text { Prabhu, MD, } \\
\text { MRCP }\end{array}$ & $\begin{array}{l}\text { Einstein Medical } \\
\text { Center, }\end{array}$ & $\begin{array}{l}\text { Supervision and revision of } \\
\text { manuscript. }\end{array}$ \\
\hline
\end{tabular}

\section{References}

1. Huang C, Wang Y, Li X, et al. Clinical features of patients infected with 2019 novel coronavirus in Wuhan, China. Lancet 2020;395:497-506.

2. Sedaghat Z, Karimi N. Guillain Barre syndrome associated with COVID-19 infection: a case report. J Clin Neurosci 2020;76:233-235.

3. Poyiadji N, Shahin G, Noujaim D, Stone M, Patel S, Griffith B. COVID-19-associated acute hemorrhagic necrotizing encephalopathy: CT and MRI features. Radiology Epub 2020 Mar 31.

4. Gilden D, Nagel MA, Cohrs RJ, et al. The variegate neurological manifestations of varicella zoster virus infection. Curr Neurol Neurosci Rep 2013;13:374.

5. Orme HT, Smith AG, Nagel MA, Bert RJ, Mickelson TS, Gilden DH. VZV Spinal cord infarct detected on diffusion weighted MRI (DWI). Neurology 2007;69:398-400.

6. Paul G, Paul BS, Singh G. Unseen face of varicella-zoster infection in adults. Indian J Crit Care Med 2016;20:731-734.

7. Casey K, Iteen A, Nicolini R, Auten J. COVID-19 pneumonia with hemoptysis: acute segmental pulmonary emboli associated with novel coronavirus infection. Am J Emerg Med 2020;38:1544.e1-1544.e3. 


\section{Neurology ${ }^{\circ}$ Clinical Practice}

COVID-19 Associated With Concomitant Varicella Zoster Viral Encephalitis

Pavan Patel, Anishee Undavia, Rabia Choudry, et al.

Neurol Clin Pract 2021;11;e219-e221 Published Online before print July 8, 2020

DOI 10.1212/CPJ.0000000000000902

This information is current as of July 8, 2020

Updated Information \&
Services

References

Subspecialty Collections

Permissions \& Licensing

Reprints including high resolution figures, can be found at:

http://cp.neurology.org/content/11/2/e219.full.html

This article cites 6 articles, 1 of which you can access for free at: http://cp.neurology.org/content/11/2/e219.full.html\#\#ref-list-1

This article, along with others on similar topics, appears in the following collection(s):

COVID-19

http://cp.neurology.org//cgi/collection/covid_19

Encephalitis

http://cp.neurology.org//cgi/collection/encephalitis

Spinal cord infarction

http://cp.neurology.org//cgi/collection/spinal_cord_infarction

Subarachnoid hemorrhage

http://cp.neurology.org//cgi/collection/subarachnoid_hemorrhage Viral infections

http://cp.neurology.org//cgi/collection/viral_infections

Information about reproducing this article in parts (figures,tables) or in its entirety can be found online at:

http://cp.neurology.org/misc/about.xhtml\#permissions

Information about ordering reprints can be found online: http://cp.neurology.org/misc/addir.xhtml\#reprintsus

Neurol Clin Pract is an official journal of the American Academy of Neurology. Published continuously since 2011, it is now a bimonthly with 6 issues per year. Copyright $\odot 2020$ American Academy of Neurology. All rights reserved. Print ISSN: 2163-0402. Online ISSN: 2163-0933.

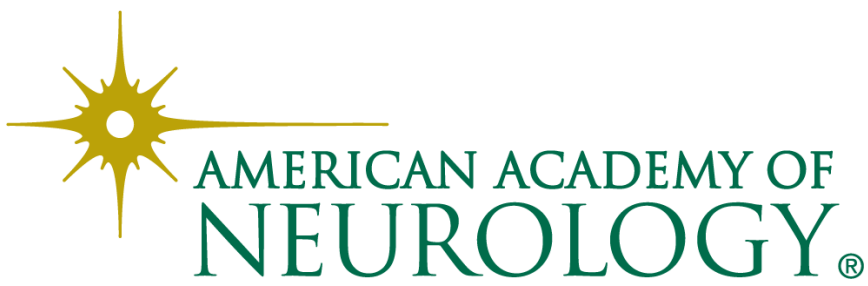

